\title{
The Gifted disabled student in the regular and the special classroom
}

\author{
Hanna David \\ Tel Aviv University, Israel (Emerita) \\ 48/18 Hakookiya St., \\ 75548 Rishon Leziyon, Israel. \\ *E-mail address: hannadav@post.tau.ac.il
}

Keywords: Giftedness; gifted disabled; double-exceptionality

\section{ABSTRACT}

The term "special education" is used, in most cases, for the education of children with learning disabilities, emotional problems, behavioral difficulties, severe physical limitations, or difficulties related to low cognitive abilities. "Gifted education", on the other hand, is used for educating the more able, children with high learning ability or special talents, creative children or children who had achieved highly in school-related or any other area, such as chess, music, painting, etc.

However, many gifted children belong to both categories. Some suffer from problems or irregularities unrelated to their giftedness, for example - learning disabilities (e.g. dyslexia, dyscalculia, dysgraphia, ADHD), or physical limitations, such as hearing loss, blindness, or paralysis. Some have to deal with issues directly or indirectly connected to their giftedness. For example: social acceptance has to do with conforming to the classroom norms, speaking about subjects considered age-appropriate, or being careful not to use "high level" vocabulary. A gifted child might find it difficult to participate in activities he or she has no interest in, not expressing feelings or ideas because they might seem odd to the peers, or thinking before using any rare or unconventional word or expression. A gifted child who is bored in the classroom might adopt behaviors such as abstention from activities, daydreaming or becoming the "classroom clown" and disturbing the teachers with voice-making, making jokes at others' expense or even at the teacher's. Such behaviors - not necessary a result of the child's giftedness but related to it - lead, in many cases, to labeling the child as "badly adjusted", "socially misfit", "isolated", or the like.

In this article I intend to describe the social and the educational difficulties the gifted child has to deal with in the regular as well as in the gifted classroom and present techniques which might help overcoming them. I will present in detail four, all gifted with either learning disabilities or emotional problems, and the successful interventions they had gone through until reaching reasonable results.

\section{THEORETICAL BACKGROUND: LEARNING VERSUS EMOTIONAL DISABILITIES}

Probst (2007) has summarized the "two kinds of gifted with double exceptionality" as follows:

When people think of a twice-exceptional child, they usually think of someone who's gifted and learning-disabled. The "second exceptionality" is typically an educational issue like dyslexia, or sometimes a physiological issue like sensory integration dysfunction. In other cases, however, a child's second condition is said to be emotional, social, or behavioral. These are described as hard-to-manage, badly behaved, or just plain odd - despite, or perhaps because of, their intelligence.

There are many differences - regarding ALL aspects of education, learning and counseling between gifted children with learning disabilities and those with emotional problems. Here are some of the main ones: 
1. In many cases it is much easier to notice a learning disability than an emotional difficulty.

2. ALL learning disabilities affect the student's achievements, while in many cases even severe psychological problems can be unnoticed at school as the student is capable of achieving highly in spite of them.

3. Once noticed, by a teacher, counselor, school psychologist or any other person in charge of the student - it is usually easier for the parents to accept the fact that their child is learning disabled than when he or she suffers from emotional problems.

4. In most cases treating a child with an emotional problem cannot be successful without full cooperation of the parents. A child with a learning disability needs the parents' support as well, but he or she can be treated even when the parents do not take an active part in the process.

\section{The double challenge: A gifted child with a learning disability}

Teaching and educating the gifted student in the regular classroom is a huge task. It involves paying special attention to ALL the student's needs: educational, social and psychological. Unfortunately, for most gifted children this task is not - and cannot be - fulfilled. Why is it so? Let us focus on some of the main difficulties of educating a gifted disabled child in a gifted or a regular class.

\section{THE GIFTED DISABLED CHILD IN A GIFTED CLASS}

In many cases gifted classes do not accept students with learning disabilities.

As for emotional disabilities - the situation is completely different. In my country, Israel, the screening for giftedness process does not include any psychological evaluation, let alone a full diagnosis. Thus, in many cases it happens, that the rate of children with psychological or emotional problems in a gifted class is higher than in any regular one. The main reasons for this situation are:

1. Israel is the only country in the world where all 7-year old children are entitled to free, public screening for giftedness. If the teacher decides they "belong" to percentile 85 of their class (Freeman et al., 2010), they are entitled to take the "stage B" giftedness examinations, and all children belonging to percentile 98.5 are labeled as "gifted". Though every year 3000-5000 new children belong to the "gifted" category (David, 2014b), in the whole country there are only 4 grade 3 classes for the gifted that operate 6-days a week. Let us look at the grade 3-6 Tel Aviv classes for elementary school students, located at the Graetz School that started operating in the 1973/4 school year. In spite of the fact that every year there are about 75 new 8-year old students belonging to percentile 98.5 , only about 20 choose the option of participating in the gifted class - which is free of charge, and includes free transportation to the school and back home from all parts of Tel Aviv. As no research has been done in the 42 years of this operating program regarding the emotional, psychological and social situation of its participants, it can only be assumed that had the program been very good according to criteria such as well-being, mental health and/or overall satisfaction of its students, a vast majority of students invited to participate would have been happy to accept the invitation. My long experience as counselor for the gifted in Israel is in accordance with the hypothesis that a substantial part of the minority of gifted children who do respond positively to that invitation suffersfrom psychological or social problems which the parents hope would be solved by learning in a gifted class. Unfortunately this is never the case.

2. The decision to take a child out of his or her school while so young is one parents usually prefer to avoid. Thus, if the child is satisfied in the regular classroom the parents would rather have the situation continue than initiate any changes. On the other hand, parents would often transfer a child with problems to a new school rather than deal with these problems.

3. Children usually do not initiate changes. Thus, when asked: "do you want to move to a gifted class?" the child would, in many cases, answer: "no". But when a child has no friends, is abused, ignored or mocked at - prospects are higher he or she would decide to transfer to 
another school. Being chosen to participate in a gifted program seems like a good option for many emotionally challenged students.

There are many sub-populations among the gifted whose needs cannot be served in a gifted classroom. Among these are many "mildly" gifted children; gifted children heavily occupied with their hobbies; many profoundly gifted children; the majority of vulnerable gifted children; numerous physically handicapped gifted children; a substantial percentage of gifted girls, and gifted boys with a tendency towards the humanities, who are considered a minority among gifted boys in general (David, 2008a). Of all these groups of gifted children, special care must be given to very sensitive gifted children and children with physical disabilities.

I. Vulnerable or highly sensitive children

Whitmore (1980) has defined the vulnerability of the gifted child as high probability of suffering from emotional stress and social conflict requiring a high level of adaptation ability, so that the inconvenience would not harm either the mental health or the overall functioning. According to her, gifted children in general suffer from some level of vulnerability, but most of them are able to use their good intellectual abilities and deal effectively with any challenge; a minority of them are not able to do that. These are the children who are at high risk of eating disorders (e.g. Leroux \& Cuffaro, 2001; Sundgot-Borgen, \& Torstveit, 2004), paralyzing perfectionism (e.g. AdderholtElliot, 1989; David, 2009; Flett et al., 1992; Speirs Neumeister, 2004; Willings, 1992), depression (e.g. Bénony et al., 2007; Jackson, \& Peterson, 2004), Self-Injurious Behavior (e.g. Wood \& Craigen, 2011) and even suicide (e.g. Cross et al., 2006; David, 2014a).

According to Terman's first study (1925), about 20\% of gifted children suffer from emotional or psychological problems, and about 5\% are considered vulnerable. Terman's longitudinal studies reinforce this finding (Terman \& Oden, 1947). Many later studies have found that gifted children are characterized by emotional and physical sensitivities (e.g. Dalzell, 1997; Edmunds, \& Edmunds, 2005; Mendaglio, 1995).

Roedell (1984) has argued that a gifted child is prone to vulnerability when not getting an opportunity to spend time with peers who are at a suitable level:

Highly gifted children experience increased vulnerability when they spend large portions of their time in inappropriate educational settings. The more a gifted child's abilities differ from the norm, the more inappropriate becomes the educational program offered in the regular classroom (ibid).

According to Kearney (1996), highly gifted children in full inclusion classrooms are at risk because of being so "far from the norm", as "[...] Giftedness is asynchronous development in which advanced cognitive abilities and heightened intensity combine to create inner experiences and awareness that are qualitatively different from the norm" (ibid).

Versteynen (1998) has summarize more than four decades of research and came to the conclusion that:

[...] gifted children are 'more' at risk for adjustment problems than their non-gifted peers; that giftedness increases a child's vulnerability to adjustment difficulties. Supporters of this view believe that gifted children are more sensitive to interpersonal conflicts and experience greater degrees of alienation and stress than do their peers, as a result of their cognitive capacities (Neihart, 1999). A significant number of researchers support this view, including Hollingworth (1942), Janos and Robinson (1985), Grossberg and Cornell (1988), Roedell (1986), Silverman (1983), and Tannenbaum (1983).

[...] Evidence suggests that the extremely gifted are more vulnerable to social and emotional problems [ibid].

Persson (2010), who had conducted research on gifted students in his homeland, Sweden, where the concept of "giftedness" does not exist in the general, egalitarian system, has come to a similar conclusion: "primary school appeared to be a hostile environment [...]" (p. 536). Person's study was done on Mensa's members:

Because there are no standard identification procedures for giftedness in Sweden, and no official recognition of giftedness or gifted education at the present time, the Mensa group 
represents both an interesting and opportune high-IQ group of intellectually gifted individuals for the study. The criterion for participating was therefore the same as the criterion to become a member of Mensa: Participants have scored an IQ score at or above 131 [...] (p. 541).

Of the 287 participants, only $25 \%$ were women; the mean age of all of them was 34.4 ; the youngest was 18 and the oldest -68 . Thus, the results of this study might reflect old memories of adults rather than immediate impressions - that are usually far from being objective. The fact that the Swedish who had taken part in the study had such negative opinions about learning in regular classes without any special programs proves that time is no "cure" to the problems a gifted child has to deal with because of not having her or his academic needs provided.

II. Children with physical disabilities

Many a time children who have a severe chronic condition or are physically disabled need to make a special effort in order to fit in among their peers. This might be a result of improper attitude, physical limitations, or both. If a physically disabled child is entitled to gifted education, by all means he or she should get it, but a special attention must be paid in order to help the child get on the school bus - or be driven by the parents; to make all adults involved be aware of the child's special needs (e.g. access to a wheel-chair; knowledge about the SOS injection in cases of a severe attack or allergy; knowledge about the location of an extra inhaler, etc.).

Literature about disabled children participating in gifted classes that operate six-days a week is quiet rare. Most of it is about such children attending out-of school enrichment activities (House \& Lapan, 1994; O’Tuel, 1994; Pyryt, 1996; Taradash, 1994). Whitmore's book (1980) is an exception: it describes a special school for gifted disabled children. Unfortunately, it is still quite common to think that "a child with special needs must not deal with too many things. He or she would rather be satisfied with what is offered to everybody else". I can still recall a mother of a deaf girl who was invited to the special gifted class at the Graez School in Tel Aviv. She came to me for a counseling session, as she knew the girl "did not learn anything in school". I could not understand why any parent would ignore the opportunity to participate in a program aimed for children at the daughter's level, but the mother said: "isn't it difficult enough for her anyway"? The mother actually punished her already "punished" daughter by deciding that since she was deaf she was not entitled to the education she deserved.

\section{Case Studies}

\section{Two dyslectic children}

As is well known, dyslexia is not "treatable" by any chemical means, like ADHD for example, nor is it prone to be "controlled" - like many emotional problems and disorders. A person with dyslexia will never be able to master reading at a similar level to other people with similar intelligence. Thus, he ${ }^{1}$ will probably not be able to be a historian, a translator, or work in any profession that requires a lot of reading, let alone mastering several languages. As a result, even when the parents of a 6-7-year old dyslectic wish to have him treated, in most cases there is a gap between their understanding of the severity of dyslexia and the actual situation, a gap that in many cases holds the treatment back. When the child starts treatment at age 10+, in most cases his self-esteem, believability in own abilities and past experiences prevent him from aspiring towards high achievements, and his low inner motivation jeopardizes the huge effort he needs to put in school assignments in order to succeed.

Let us look at these two examples.

\section{Adi - the 7-year old dyslectic child}

Adi first met me at age 7. He was not diagnosed as having dyslexia, but rather "just" ADHD. Adi lived about $200 \mathrm{~km}$ from my office. Thus, had I known he had had dyslexia I would not have

\footnotetext{
${ }^{1}$ The subject will be referred to as "he" because in all dyslexia studies the male/female rate found had been from 2:1 to 15:1 (Finucci et al., 1981; Harlaar et al., 2005; Hawke et al., 2007, 2009; Miles et al., 1998; Shaywitz et al., 1990; Stevenson, 1990 Vogel, 1990)
} 
accepted him for treatment that was to take, according to my experience, at least 2 years until he would regain he strengths, activate his motivation, and his parents would find suitable private tutors, tutors capable of giving answer: to all his needs as a gifted dyslectic child.

Unfortunately, that was not the case. During my first meeting with Adi, a week after the intake meeting with his parents, I realized he was dyslectic. Usually when parents do not suspect their child suffers from a severe developmental or learning disability, it takes time till they "digest" the bad news. However, in Adi's case I knew that if I suggested that Adi would be diagnosed right away they would resist and that was to be the end of the treatment. Thus, I started our sessions with teaching Adi simple reading strategies, such as isolating each word, magnifying the page, triplespacing the lines, and using magnifying glass while reading. As it was the father who brought Adi to me I asked him to sit with us during the sessions, so that he could learn how these techniques worked.

Unfortunately, this intervention has no "happy ending". While Adi was still meeting me, his emotional situation improved from one meeting to the next (about substantial improvement from one session to the next one in treatment see David, 2014c; Dour et al., 2013). But However, Adi's parents decided to stop the treatment after just 7 sessions. They told me they believed they would find the way to help him "now, after watching you talk to Adi, teach Adi, and catch his interest in a variety of subjects". But 3 years later I received a mail from the father, saying Adi had stopped going to school at all.

\section{Guy - Another 7-year old dyslectic boy}

Guy was a shy, well behaved 7-year old boy. I first met his parents who wanted to know more about dyslexia - the diagnosis he received after he was referred to a full psycho-diagnosis evaluation. This evaluation revealed an unconceivable gap between the expected achievements from such a quick, easy to handle, diligent and good-natured boy, as he was described by the whole staff of his kindergarten, and the learning difficulties he had right from the beginning of class 1 .

During our first meeting I learnt how intelligent Guy was and how much he was craving for learning, despite his disability. When I asked him: “do you like math?" he said: "I love numbers, I love shapes, I wish I could learn more than what is offered in my classroom". Thus, in order to help him I suggested to his parents that he took private lessons with a math teacher who was holding a $\mathrm{PhD}$ degree, an expert of teaching highly gifted children, who preparesd his students to start their math degree while still in school and get at least their BSc, preferably MSc, prior to their military service (about this program see: David, 2008b, c). Though his teacher had not had experience with dyslectic students he told him during their first lesson: "do you know that Einstein was dyslectic as well?" From that moment Guy decided to do his best in order to satisfy his beloved teacher, and instead of the daily 10 minutes he had to invest in his homework his parents found it hard to stop him memorize the multiplication table after an hour...

In addition to his math teacher Guy's parents hired an undergraduate student for practicing reading with Guy and helping him with his homework 5 days a week. In addition, every day one of them was reading aloud for him at least one hour from a book Guy had chosen, as his own reading was on a much lower level than the books he really liked. This reading increased his vocabulary, knowledge, and curiosity. Thanks to the daily routine of reading in spite of the difficulties and homework doing, Guy did not suffer from any psychological effects that accompany dyslexia in most cases, such as low self-confidence, and low motivation. He is currently a gifted boy who is interested in many areas, loved by his friends, and yes - also has dyslexia.

\section{ADHD and ODD}

Attention Deficit [Hyperactivity] Disorder [ADHD] and Oppositional Defiant Disorder [ODD] are two separate problems which occur in different frequencies as well as a variety of intensities in all examined populations. However, the ODD percentage among ADHD children is much higher than in the general population. According to Faraone \& Biederman (1997), 45\% to $84 \%$ children and adolescents with ADHD have oppositional defiant disorder. Other estimations of 
this co-morbidity have been 20-80\% (Ghanizadeh, 2009; Hare et al., 1980; Jensen et al., 1997; Lavigne et al., 2001; Mick et al., 2003).

Even if this is an over-evaluation, it is clear that special attention and care should be given to children with ADHD in order to minimize the potential long-term influences of ODD. Barkley et al. (1999) have also written about the high comorbidity between ADHD and ODD. Doggett (2004) has stated that:

Children with ADHD can be anxious, shy, socially withdrawn, moderately unpopular with classmates, poor at sports, and have poor school performance. Children diagnosed with ADHD are more likely to receive a co-diagnosis of an anxiety or affective disorder, and tend to be more anxious or avoidant of stressful situations. Teachers report that ADHD children are more distant (e.g. they have daydreams, fantasies), are more lethargic, and more impaired in perceptual-motor speed (Erk, 2000). Hynd et al. (1991) concluded that children with ADHD are more socially withdrawn, have a slower cognitive tempo, are more self-conscious, and have a higher incidence of developmental learning disorders. Other research suggested that children with ADHD have increased difficulties with development of mathematical abilities, they experience increased language delays (Erk, 2000), and have difficulties with reading (Pisecco et al., 2001).

Of the children that are diagnosed, 30-50 percent are also thought to have co-existing or associated psychiatric/behavioral disorders (Erk, 2000; Kendall et al., 1980; Sales, 2000). As many as 60 percent of children with ADHD will meet the criteria for oppositional-defiant disorder, and up to 50 percent will eventually meet the criteria for conduct or mood disorder (Brown, 2000). Depression, anxiety, and tics are also common (Kollins et al., 2001). The incidence of these co-existing disorders is more likely for children whose parents have a history of psychopathology or whose families are disorganized or dysfunctional. Children with Tourette's Syndrome, lead poisoning, fetal alcohol syndrome, retardation, early trauma, and seizure disorders frequently have ADHD (Doggett, 2004, p. 71).

ODD should be treated as soon as possible. Usually it is not discovered when the child is very young, but for gifted children the age of the first signs that might give a clue about potential ODD is usually much earlier than among regular children. Barkley (2013) has designed an intervention program for 2-12-year old children with behavioral problems that might develop into ODD. According to him:

The success of the program greatly hinges in the child's level of receptive language development, in that the child must have the capacity to comprehend parental commands, directives or instructions (ibid, p. 2).

Under the age of 2 children usually do not have high enough communication skills because of their verbal low abilities. Thus we can conclude that when applied on gifted children the minimal and the maximal ages might be lower, as high verbal abilities, developed at a young age, are typical characteristics of gifted children, and their development might be accelerated in comparison to that of regular children. As a result in many cases it would be much less effective to have gifted children older than 10, for example, participate in the program.

\section{ELI - THE ADHD CHILD WITH OPPOSITIONAL DEFIANT DISORDER [ODD]}

Eli had been diagnosed at age 6 as having a mild level of ADHD. However, he was considered: "very hard to manage since ever" as his mother expressed. Both parents agreed it would be good to start treating him with Ritalin right after the diagnosis, as they were afraid he would have been labeled as "a difficult student" otherwise (about treating very young children with Ritalin see, for example, David, 2011).

It took just a few weeks to notice that the Ritalin that caused the 4-hour "break" in Eli's "unbearable behavior" - the mother's expression - was not enough. Because of Eli's behavior the teacher had invited the parents at least once a week to the school to come for a discussion of the situation; when they did they had to listen to the teacher's complaints about their son's "bad behavior". They tried to explain the teacher time and again that it did not help when she told them 
that Eli did not want to do cooperative tasks, refused to obey her, quarreled with anybody who tried to argue with him, always found excuses for not doing his homework, did not complete class assignments and did not bring the necessary materials to school. The parents were afraid to ignore the teacher's calls as they felt the teacher "hated" their son, so they pretended these meetings were helpful even when in fact they were not.

Eli took his Ritalin after breakfast, because his appetite was severely influenced by the pill, but after taking it he could not eat for 6 hours, namely 2 hours after the Ritalin stopped influencing his system. However, soon it was clear that this amount of Ritalin was not enough for him. After the appointment with the psychiatrist who had prescribed him Ritalin in the first place he started taking the 6-hour pill (Ritalin SR20). When, due to his very high abilities, he complained about being bored in school, and thus started going to the local chess club and also took private English classes, his psychiatrist prescribed him the slow-release 8-hour Ritalin (Ritalin LA). This pill almost paralyzed his appetite for 10 hours.

However, Eli's problems - both in school and at home - did not come to an end by taking Ritalin. While at school the main problem his parents heard time and again were disciplinary, at home he quarreled endlessly with his younger brother. It came to a point his parents preferred not to go out with both their children rather than deal with Eli's violence against his brother and the brother's shouting, yelling and crying in public. As for Eli's endless arguments - his parents did not know how to end them. Whenever they suggested any activity Eli would try to manipulate them by explaining why it was better to do something else or do whatever was offered some other time.

The treatment process with Eli took about 18 months. It was intensive, had ups and downs, but at its end Eli did not fit into the "ODD criteria" as 4 of the main symptoms of the disorder almost disappeared (David, in press, a). Helping a young child overcome this severe disorder is of double importance: 1. Eli was never labeled as an ODD child and thus he escaped prejudices, preassumptions causing negative attitudes and negative judgments that accompany children diagnosed with ODD (Allday et al., 2011; Lahey et al., 1987). 2. When a child does not have the ODD criteria any longer he will not grow up to be an adolescent with conduct disorder, a disorder considered even more severe than ODD and very hard to get rid of.

\section{LEO - AN ADOLESCENT BOY WITH SEVERE COMMUNICATION PROBLEMS}

When I first met Leo he was a 15-year old boy who just started learning in a scientificoriented track in grade 10 at the local senior high school. Until then, since he started public kindergarten at age 4, he had a more-or-less stable group of friends that accompanied him through pre-school, elementary- and junior high school. At the beginning of the year the class teacher had noticed that Leo was spending the breaks by himself, that he had a distant look, never joined any group of students laughing at jokes or conversing loudly. The school counselor was informed about it, and after meeting Leo she suggested to his parents that he should take the full battery of psychodidactic diagnosis.

Leo had very high abilities in math and physics. He was never a "party animal", but he was always taking a part in his peers' activities such as scouts, ${ }^{2}$ going out to the mall for a hamburger, pizza, etc., or watching a movie either in a private house or in a movie-hall. During his childhood and early adolescence Leo was frequently nick-named: "an astronaut", "Scatterbrain professor" or even "nerd" both by his school mates and peers from his neighborhood. He did not find it easy to start a relationship with any of his peers, but he always liked to help his schoolmates with their homework and never said "no" when they asked him to copy his homework. From the beginning of junior high school his parents' home was full of children before each math or science exam, these "visitors" came to get free private lessons and were most welcome. His mother, fully aware of Leo's social difficulties, was glad to bake her best cookies for her son's schoolmates, and buy light drinks for them. She used to say: "it does not matter why they come; the important thing is that Leo has friends".

\footnotetext{
${ }^{2}$ In Israel all scouts' activities are mixed-sex.
} 
The situation seemed to change since the beginning of grade 10 . The group of children that was used to Leo for years was not there for him any longer. ${ }^{3}$ The pressure "to be like everybody else" was not possible for Leo who just could not do it. Thus, the magic term - "diagnosis" - was immediately suggested.

Leo's parents met me after setting a date for the first part of his diagnosis so time was quite tight. The parents described Leo as an adolescent who had to be taught, since early childhood, "what his little sister understood without learning". They gave many examples: Leo found it hard to understand when other people were not interested in what he wanted to tell them; when a praise was given ironically - that it meant the opposite; which questions he was not to ask adults and which not even his peers; why he was expected to laugh at a joke even when he did not think it was funny, and many more. Leo's mother had concerns about his future military service - which is compulsory in Israel, ${ }^{4}$ and suggested that maybe he was a good candidate for the special track of basic training for youngsters with Asperger's syndrome. Now, that the word "Asperger's" was first said, I knew this was my opportunity to conclude the meeting by setting a plan for the future.

I explained the parents that Asperger's was a disorder belonging to the Autistic spectrum but it was not wise to label a child who fully functions in everyday life as well as in school as having it. Leo, I added, had severe communication problems, difficulties in understanding other peoples' thoughts or perceiving their feelings. I assured them that this could still improve by treatment, especially because Leo was still - physically, emotionally and sexually an adolescent, and thus he preserved some amount of flexibility. I suggested that maybe it was better to focus on the current problem - making a decision about the diagnosis - rather than decide anything about future things that might substantially change in the next two years.

At this point the father asked: "so what is the purpose of the diagnosis"? I said that I did not know and asked if they believed the school could offer them permanent treatment for Leo's communication problems. Instead of an answer the mother started laughing. She said that the school psychologist met her son just once during the previous 9 years, so she had stopped hoping that the school could do anything "a long time ago". The mother asked me: "do you have an idea what would be written in the diagnosis?" I said that I did not know, but added, that probably it was going to include statements they would not be very glad to read, including professional terms that were not going to help either them or Leo. I also said that most probably the diagnosis was to include a suggestion of treatment in the "recommendations" part. "So why do we need it?" She asked. "I do not think you need it" was my answer. "We all know Leo had a problem since early childhood, and we know exactly what the problem was, so we do not need it to be written", the mother said. "Indeed, I do not think you need it" was my answer. "You had been trying to deal with it during the years in a variety of ways: Leo had therapy in a group for children with communication- and emotional problems, the parents had 6 years of parents' instructions, and Leo had been treated by a psychologist who was an expert in children with Asperger's. Now it is time to decide about further individual intervention, as it might help him a lot".

As is well known that diagnosis per se is not a solution to any problem of any child. I explained the parents that a diagnosis was recommended in cased of suspecting the existence of a problem, where the diagnosis could either prove or disprove this suspicion, but in Leo's case we knew exactly what the problem was, and there was no visible advantage of labeling Leo as disabled.

In addition, in Israel children's confidentiality in quite frequently compromised "by the attitude of the school staff in the classroom, in the teachers' room and during meetings with the parents" (David, 2012a, p. 11). Even when diagnosed privately, namely, the parents pay for the diagnosis, there is no way to assure that once the diagnosis is read by any staff member of the school it would not be exposed to other people as well (David, 2012a, 2012b, Rachmel, 2012). Thus any diagnosis that might result in unfavorable results, such as nicknaming a student "the nerd" or even "the Aspi" should be prevented.

\footnotetext{
${ }^{3}$ In Israel high the process of track-choosing ends at the beginning of high school, at grade 10.

${ }^{4}$ Military compulsory service is 3 -year long for 18 -year old men and 2 for women.
} 
The parents were advised to choose between individual treatment and group therapy with adolescents who had communication problems. They chose both. Leo found a male therapist who helped him accept his limitations, answered in detail the questions Leo had regarding day-to-day social interactions, and helped him understand the causes of unsuccessful events, such as parties he did not feel a part of or afternoon gathering when he did not dress appropriately for the planed activity, in order to avoid similar events in the future. In the group Leo learnt to start a conversation, how and when to interrupt a discussion in order to say what he had to, and even how to interpret some of the more common expressions in order to be better in what he called "my worst area: reading faces".

Leo had finished high school successfully, with an excellent matriculation certificate. He serves his 3-year-compulsory military service in a technical job close to his home, so he did not have to sleep away except for the 4-week basic training. Right after the army he started his engineering studies at the Technion, The Israeli Institute of Technology, and received his BSc degree "cum ladue".

\section{CONCLUSION}

The gifted child does not have to be "integrated" in the regular classroom, as most gifted children, all over the world, do not actually have a choice but to learn in a classroom that does not give an answer to their psychological, social, and certainly not their educational needs. The learning-disabled child is, many a time, "integrated" in the regular classroom, more or less successfully. The student with double exceptionality, gifted and disabled, almost never finds a place where he would "fit in". Many teachers, headmasters and headmistresses, school counselors and psychologists are not aware of the fact that such students exists, let alone are willing to be more considerate towards them, learn more, and open their hearts in order to make the lives of these students more tolerable.

When a student needs any kind of educational or psychological intervention there must be full collaboration among the school, the parents and the therapist or the institute in charge of providing emotional help. Unfortunately, in many cases schools fails to be a part of this triangle. In more severe disabilities, like dyslexia, it happens quite often that the child is pushed out of school, which recommends a special education institute for her or him. When gifted children learn in special education classes, where most children are far from matching their cognitive abilities, it might be a continuous torture. Even when the disability is considered "milder", such as ADHD, life might be unbearable for many gifted students who cannot sit quietly as required, have emotional bursts, and are simply unable to concentrate when their tasks are boring - which is the case most of the time for most gifted children.

It should be thus recommended that all teachers learn more about learning disabilities and emotional and social problems among children, as well as about giftedness. Until this is done many gifted children will pay a very high price. Their wellbeing will be deteriorating, their academic achievements will be lower, and their ability to become adults who contribute their talents and gifts to the world in general and to their society in particular will disappear.

\section{References}

[1] Adderholt-Elliott, M. (1989). Perfectionism \& underachievement. Gifted Child Today, 19-21.

[2] Allday, R.A., Duhon, G.J., Blackburn-Ellis, S., \& Van Dycke, J.L. (2011). The Biasing Effects of Labels on Direct Observation by Preservice Teachers. Teacher Education and Special Education, 34(1), 52-58.

[3] Amend, E.R., \& Beljan, P. (2009). The Antecedents of Misdiagnosis: When Normal Behaviors of Gifted Children Are Misinterpreted As Pathological. Gifted Education International, 25(2), 131-143. 
[4] Barkley, R.A. (2013). Defiant Children: A Clinician's Manual for Assessment and Parent Training (Third Edition). New York: Guilford Publications, Inc.

[5] Barkley, R.A., Edwards, G.H., \& Robin, A.L. (1999). Defiant Teens, First Edition: A Clinician's Manual for Assessment and Family Intervention. New York: Guilford Publications, Inc.

[6] Benito Mate, Y. Giftedness and associated disorders: Oppositional defiant disorder. Retrieved on 20 May 2014 from the "Huerta del Rey" Center, Valladolid, Spain: http://www.nepes.eu/?q=node/440

[7] Bénony, H., Van Der Elst, D., Chahraoui, K., Bénony, C., \& Marnier, J.P. (2007). Lien entre dépression et estime de soi scolaire chez les enfants intellectuellement précoces [Link between depression and academic self-esteem in gifted children]. Encephale, 33(1), 11-20.

[8] Brown, M.B. (2000) 'Diagnosis and Treatment of Children and Adolescents with AttentionDeficit/Hyperactivity Disorder', Journal of Counseling and Development, 78(2): 195-203.

[9] Bussing, R., Fernandez, M., Harwood, M., Hou, W., Garvan, C.W., Eyberg, S.M., \& Swanson, J.M. (2008). Parent and Teacher SNAP-IV Ratings of Attention Deficit Hyperactivity Disorder Symptoms: Psychometric Properties and Normative Ratings from a School District Sample. Assessment, 15(3), 317-328.

[10]Cordeiro, M.L., Farias, A.C., Cunha, A., Benko, C.R., Farias, L.G., Costa, M.T., Martins, L.F., \& McCracken, J.T. (2011). Co-Occurrence of ADHD and High IQ: A Case Series Empirical Study. Journal of Attention Disorders, 15(6), 485-490.

[11]Cross, T.L., Cassady, J.C., \& Miller, K.A. (2006). Suicide ideation and personality characteristics among gifted adolescents. Gifted Child Quarterly, 50(4), 295-306.

[12]Dalzell, H.J. (1997). Giftedness: Infancy to adolescence - a developmental perspective. Roeper Review, 20(4), 259-264.

[13] David, H. (2008a). Integration or separate classes for the gifted? The Israeli view. Australasian Journal of Gifted Education, 17(1), 40-47.

[14]David, H. (2008b). Mathematical Giftedness: The Mathematics Acceleration Program at the Tel Aviv University. Gifted Education Press, 22(3), 4-9 [Summer 2008].

[15]David, H. (2008c). The Mathematics Acceleration Program of the Tel Aviv University (19701999). In R. Leikin (ed.), Proceedings of The 5th International Conference Creativity in Mathematics and the Education of Gifted Students (pp. 427-429). Haifa, Israel, February 24-28, 2008.

[16]David, H. (2009). Perfectionism among Ultra-Orthodox Israeli youth. In T.S. Yamin (Ed.), Proceedings of the Annual Conference of the International Centre for Innovation in Education (ICIE) held in Paris-France (July 1-4, 2008) (pp. 705-714). Ulm, Germany: ICIE.

[17]David, H. (2011). Learning disabilities, Attention deficit (Hyperactivity) Disorder, and giftedness: Two case-studies. Gifted Education Press, 25(3), 2-9. Retrieved on 16 June 2014 from the Davidson Institute database: http://www.davidsongifted.org/db/Articles_id_10713.aspx

[18]David, H. (2012a). Ethical issues in educating and counseling the gifted. Gifted Education Press, 26(3), 7-13.

[19]David, H. (2012b). Response to the letter of Shlomit Rachmel, the Director of the Division for Gifted and Outstanding Students, The Ministry of Education, Israel, on my article: Ethical issues in educating and counseling the gifted [Gifted Education Press, 26(3), 7-13]. Gifted Education Press, 26(4), 19-20. 
[20]David, H. (2014a). Diagnosis of the gifted in Israel. Gifted Education International, 30(1), 5760.

[21]David, H. (2014b). The gifted child in school (Hebrew). Retrieved on 10 June 2014 from: http://www.hebpsy.net/articles.asp?id=3105

[22]David, H. (2014c). On the first substantial improvement in treatment of young children (Hebrew). Retrieved on 18 July 2014 from http://www.hebpsy.net/articles.asp?id=

[23]David, H. (in press, a). Suicide threats and suicide attempts among the gifted.

[24]David, H. (in press, b). Overcoming Oppositional Defiant Disorder: Case study of a 7-year old boy.

[25]Doggett, A.M. (2004). ADHD and Drug Therapy: is it Still a Valid Treatment? Journal of Child Health Care, 8(1), 69-81.

[26]Dour, H.J., Chorpita, B.F., Lee, S., \& Weisz, J.R. (2013). Sudden gains as a long-term predictor of treatment improvement among children in community mental health organizations. Behaviour Research and Therapy, 51(9), 564-572.

[27]Edmunds, A.L. \& Edmunds, G.A. (2005). Sensitivity: A double-edged sword for the preadolescent and adolescent child. Roeper Review, 27, 69-77.

[28]Erk, R.E. (2000) 'Five Frameworks for Increasing Understanding and Effective Treatment of Attention-Deficit/Hyperactivity Disorder: Predominantly Inattentive Type', Journal of Counseling and Development, 78(4), 389-399.

[29]Faraone, S. V., \& Biederman, J. (1997). Do attention deficit hyperactivity disorder and major depression share familial risk factors? Journal of Nervous Mental Disorders, 185, 533-541.

[30]Finucci, J.M., \& Childs, B. (1981). Are there really more dyslexic boys than girls? In: A. Ansara, N. Geschwind, A. Galaburda, M. Albert \& N. Gartrell (eds.) Sex differences in dyslexia. (pp. 1-9). Townson, MD: Orton Dyslexia.

[31]Fite, P.J., Greening, L., Stoppelbein, L., \& Fabiano, G.A. (2009). Confirmatory Factor Analysis of the Antisocial Process Screening Device with a Clinical Inpatient Population. Assessment, 16(1), 103-114.

[32]Flett, G.L., Blankstein, K.R., Hewitt, P.L. \& Koledin, S. (1992). Components of perfectionism and procrastination in college students. Social Behavior and Personality, 20(2), 85-94.

[33]Freeman, J, Raffan, J. \& Warwick, I. (2010). World-wide Provision to Develop Gifts and Talents. An International Survey. Retrieved on 10 June 2014 from: http://www.joanfreeman.com/pdf/towereport.pdf

[34] Ghanizadeh, A. (2009). Psychiatric comorbidity differences in clinic-referred children and adolescents with ADHD according to the subtypes and gender. Journal of Child Neurology, 24(6), 679-684.

[35] Grossberg, LN., \& Cornell, D.G. (1988). Relationship between personality adjustment and high intelligence: Terman versus Hollingworth. Exceptional Children, 55, 266-272.

[36]Hare, W.A., Inverso, M.J., \& Yolton, R.L. (1980). Neuropathology of the hyperkinetic child. Journal of the American Optometric Association, 51(1), 27-30.

[37]Harlaar N., Spinath, F.M., Dale, P.S., \& Plomin, R. (2005). Genetic influences on early word recognition abilities and disabilities: A study of 7-year-old twins. Journal of Child Psychology and Psychiatry, 46, 373-384. 
[38]Harrison, J.R., Vannest, K.J. \& Reynolds, C.R. (2011). Behaviors That Discriminate ADHD in Children and Adolescents: Primary Symptoms, Symptoms of Comorbid Conditions, or Indicators of Functional Impairment? Journal of Attention Disorders, 15(2), 147-160.

[39] Hawke, J.L., Wadsworth, S.J., Olson, R.K., \& DeFries J.C. (2007). Etiology of reading difficulties as a function of gender and severity. Reading and Writing, 7(20), 13-25.

[40]Hawke, J.L., Olson, R.K., Willcutt, E.G., Wadsworth, S.J., \& DeFries, J.C. (2009). Gender ratios for reading difficulties. Dyslexia, 15(3), 239-242.

[41]Hollingworth, L.S. (1942). Children above IQ 180, Stanford-Binet. New York: World Book Company.

[42]House, E.R. \& Lapan, S. (1994). Evaluations of programs for disadvantaged gifted students. Journal for the Education of the Gifted, 17(4), 441-466.

[43]Hynd, G.W., Semrud-Clikeman, M., Lorys, A.R., Novey, E.S., Eliopulos, D. and Lyntinen, H. (1991) 'Corpus Callosum Morphology in Attention Deficit-Hyperactivity Disorder: Morphmetric Analysis of MRI', Journal of Learning Disabilities, 24(3), 141-146.

[44] Jackson, S.P., \& Peterson, J. (2004). Depressive disorders in highly gifted adolescents. Journal of Secondary Gifted Education, 14(3), 175-186. Retrieved on 11 June 2014 from: http://www.sengifted.org/archives/articles/depressive-disorder-in-highly-gifted-adolescents

[45]Janos, P.M., \& Robinson, N.M. (1985). Psychosocial development in intellectually gifted children. In F.D. Horowitz and M. O'Brien (Eds.). The gifted and talented: Developmental perspectives (pp. 149-195). Washington, DC: American Psychological Association.

[46] Jensen, P.S., Martin, D., \& Cantwell, D.P. (1997). Comorbidity in ADHD: implications for research, practice, and DSM-V. Journal of the American Academy of Child and Adolescent Psychiatry, 36(8), 1065-1079.

[47]Kearney, K. (1996). Highly Gifted Children in Full Inclusion Classrooms. Highly Gifted Children, Summer/Fall 1996, 12(4). Retrieved on 11 June 2014 from: http://www.hollingworth.org/fullincl.html

[48]Kendall, P.C., Padever, W. and Zupan, B. (1980) Developing Self-control in Children: A Manual of Cognitive-behavioral Strategies. Minneapolis: University of Minnesota.

[49]Kollins, S.H., Barkley, R.A., \& DuPaul, G.J. (2001) 'Use and Management of Medications for Children Diagnosed with Attention-Deficit Hyperactivity Disorder (ADHD)', Focus on Exceptional Children 33(5), 1-24.

[50]Lahey, B.B., Schaughency, E., Hynd, G., Carlson, C., \& Niever, C. (1987). Attention deficit disorder with and without hyperactivity: Comparison of behavioral characteristics of clinic referred children. Journal of the American Academy of Child and Adolescent Psychiatry, 26, 718-723.

[51]Lavigne, J.V., Cicchetti, C., Gibbons, R.D., Binns, H.J., Larsen, L., \& DeVito, C. (2001). Oppositional defiant disorder with onset in preschool years: longitudinal stability and pathways to other disorders. Journal of the American Academy of Child and Adolescent Psychiatry, 40(12), 1393-1400.

[52]Leroux, J.A., \& Cuffaro, M.A. (2001). Adolescent Females and Body Image: Eating Disorders and Educational Implications. Gifted Education International, 16(1), 11-19.

[53] Mendaglio, S. (1995). Sensitivity among gifted persons: A multi-faceted perspective. Roeper Review, 17(3), 169-172. 
[54]Mick, E., Biederman, J., Faraone, S.V., Sayer, J., \& Kleinman, S. (2002). Case-control study of attention-deficit hyperactivity disorder and maternal smoking, alcohol use, and drug use during pregnancy. Journal of the American Academy of Child and Adolescent Psychiatry, 41(4), 378385 .

[55]Miles, T.R., Haslum, M.N., \& Wheeler, T.J. (1998). Gender ratio in dyslexia. Annals of Dyslexia, 48(1), 27-55.

[56]Neihart, M. (1999). The impact of giftedness on psychological well-being. Roeper Review, 22(1), 10-17. Retrieved on 11 June 2014 from: http://talentdevelop.com/articles/TIOGOPW.html

[57]O'Tuel, F. S. (1994). APOGEE: Equity in the identification of gifted and talented students. Gifted Child Quarterly, 38(2), 75-79.

[58]Persson, R.S. (2010). Experiences of Intellectually Gifted Students in an Egalitarian and Inclusive Educational System: A Survey Study. Journal for the Education of the Gifted, 33(4), 536-569.

[59]Pisecco, S., Baker, D.B. and Silva, P.A. (2001) 'Boys with Reading Disabilities and/or ADHD: Distinctions in Early Childhood', Journal of Learning Disabilities, 34(2), 98-106.

[60] Probst, B. (2007). When your child's exceptionality is emotional: Looking beyond psychiatric diagnosis. Retrieved on 10 June 2014 from: http://www.sengifted.org/archives/articles/whenyour-childs-exceptionality-is-emotional-looking-beyond-psychiatric-diagnosis

[61] Pyryt, M.C. (1996). IQ: Easy to bash, hard to replace. Roeper Review, 18(4), 255-258.

[62]Rachmel, S. (2012). Letter to the editor. Response to Hanna David's article: Ethical issues in educating and counseling the gifted [Gifted Education Press, 26(3), 7-13]. Gifted Education Press, 26(4), 18.

[63]Roedell, W. (1984). Vulnerabilities of highly gifted children. Roeper Review, 6(3), 127-130. Retrieved on 11 June 2014 from: http://www.davidsongifted.org/db/Articles_id_10065.aspx

[64]Roedell, WC. (1986). Socioemotional vulnerabilities of young gifted children. Journal of Children in Contemporary Society, 18(3-4), 17-29.

[65]Rutter, M., Caspi, A., Fergusson, D., Horwood, L.J., Goodman, R., Maughan, B., Moffitt, T.E., Meltzer, H., \& Carroll, J. (2004). Sex differences in developmental reading disability: New findings from 4 epidemiological studies. JAMA, 291(16), 2007-2012.

[66] Sales, A. (2000) 'Substance Abuse and Disability', Substance Abuse and Counseling. A Perspective. ERIC document reproduction service, no. 440352.

[67] Shaywitz, S.E., Shaywitz, B.A., Fletcher, J.M., \& Escobar, M.D. (1990). Prevalence of reading disability in boys and girls. Results of the Connecticut Longitudinal Study. JAMA, 264(8), 9981002.

[68] Shaywitz, B.A., \& Shaywitz, S.E. (1991). Comorbidity: A Critical Issue in Attention Deficit Disorder. Journal of Child Neurology, 6(1), suppl: pp. S13-S22.

[69] Silverman, LK. (1983). Personality development: The pursuit of excellence. Journal for the Education of the Gifted, 6(1), 5-19.

[70] Speirs Neumeister, K.L. (2004). Factors influencing the development of perfectionism in gifted college students. Gifted Child Quarterly, 48(4), 259-274.

[71] Stevenson J. (1990). Identifying sex differences in reading disability: Lessons from a twin study. Reading and Writing, 4, 307-326. 
[72] Sundgot-Borgen, J., Torstveit, M.K. (2004). Prevalence of Eating Disorders in Elite Athletes Is Higher Than in the General Population. Clinical Journal of Sport Medicine, 14(1), 25-32. Retrieved on 11 June from: http://journals.lww.com/cjsportsmed/Abstract/2004/01000/Prevalence_of_Eating_Disorders_in _Elite_Athletes.5.aspx

[73] Tannenbaum, AJ. (1983). Gifted children: Psychological and educational perspectives. New York: Macmillian.

[74] Taradash, G. (1994). Extending educational opportunities for middle school gifted students. Gifted Child Quarterly, 38(2), 89-94.

[75] Terman, L.M. (1925). Mental and physical traits of a thousand gifted children. Genetic studies of genius, vols. 1 \& 2. Stanford: Stanford UP. Vol. 1 retrieved on 4 August 2013 from: http://ia600301.us.archive.org/10/items/geneticstudiesof009044mbp/geneticstudiesof009044mb p.pdf

[76] Terman, L.M. \& Oden, M.H. (1947). Genetic studies of genius. vol. 4: The Gifted Child Grows Up: Twenty-five years' follow-up of a superior group. Stanford UP, Stanford CA.

[77] Versteynen, L. (1998). Issues in the social and emotional adjustment of gifted children: what does the literature say? The New Zealand Journal of Gifted Education, 13(1). Retrieved on 11 June 2014 from: http://www.giftedchildren.org.nz/apex/v13art04.php

[78] Vogel, S.A. (1990). Gender differences in intelligence, language, visual-motor abilities, and academic achievement in students with learning disabilities: A review of the literature. Journal of Learning Disabilities, 23, 44-52.

[79] Whitmore, J.R. (1980). Giftedness, conflict, and underachievement. Boston, Massachusetts: Allyn and Bacon Inc.

[80]Willings, D. (1992). Burnout among Teachers of the Gifted and Gifted Adults. Gifted Education International, 8(2), 107-113.

[81] Wood, S.M., \& Craigen, L.M. (2011). Self-Injurious Behavior in Gifted and Talented Youth: What Every Educator Should Know. Journal for the Education of the Gifted, 34(6), 839-859. 